Personalidade Acadêmica Homenageada:

Augustus B. Cochran III (Agnes Scott College)

\title{
ENCARCERAMENTO FEMININO POR ASSOCIAÇÃO AO TRÁFICO NO ESTADO DE MINAS GERAIS: A GUERRA ÀS DROGAS COMO FERRAMENTA DE OPRESSÃO À MULHER
}

\section{FEMALE CLOSURE FOR TRAFFIC ASSOCIATION IN THE STATE OF MINE GENERAL: THE DRUG WAR AS A TOOL FOR OPPRESSION TO WOMEN}

MARIA LUÍZA DUTRA BARBOSA

Graduanda em Direito, modalidade integral - Escola Superior Dom Helder Câmara ESDHC. Belo Horizonte - MG. E-mail: marialuizaad@gmail.com

\section{PEDRO HENRIQUE SENA SAYÃO} Graduando em Direito, modalidade integral - Escola Superior Dom Helder Câmara ESDHC. Belo Horizonte - MG. E-mail: pedrosenasayao@gmail.com

CAIO AUGUSTO SOUZA LARA Mestre e Doutor em Direito pela Faculdade de Direito da Universidade Federal de Minas Gerais - UFMG. Professor da Escola Superior Dom Helder Câmara. Pesquisador associado ao Programa RECAJ-UFMG - Acesso à Justiça e Solução de Conflitos. Secretário de Comunicação do Conselho Nacional de Pesquisa e Pósgraduação em Direito - CONPEDI. Belo Horizonte-MG. E-mail: caiolarabh@yahoo.com.br. 


\section{Personalidade Acadêmica Homenageada:}

Augustus B. Cochran III (Agnes Scott College)

\section{RESUMO}

O tema-problema da pesquisa que se pretende desenvolver é a opressão da mulher por parte não só da sociedade, mas também do estado por meio de diversos fatores que as levam a entrar para o mundo do crime. Observa-se que o aumento da população carcerária feminina por associação ao tráfico no estado de Minas Gerais, está ligada também à função subalterna que elas exercem em face do homem no crime organizado. Em virtude do papel das mulheres no tráfico de drogas, depreendese que o âmbito do crime replica os marcadores de gênero da sociedade. A rede de tráfico de drogas é marcada pela divisão social e sexual do trabalho, ou seja, a mulher ocupa cargos coadjuvantes, dada a sua condição de gênero. Em razão de essas funções estarem vinculadas diretamente ao produto final do crime, as mulheres estão mais expostas e por isso se encontram em condição de maior vulnerabilidade no que tange ao possível aprisionamento. Tal fato acarreta no aumento desproporcional do encarceramento feminino em comparação com o masculino, já que este, por ocupar postos mais altos na escala hierárquica do tráfico, está menos suscetível ao flagrante e posteriormente ao aprisionamento. Os efeitos das políticas antidrogas no Estado são alarmantes, pois as mulheres, abandonadas após o encarceramento, além de não serem visitadas, acabam tendo grande dificuldade na manutenção das despesas do lar após o encarceramento. Segundo relatório do Centro de Estudos de Criminalidade e Segurança Pública, CRISP, 70\% das encarceradas na unidade prisional Estevão Pinto, em Belo Horizonte, tinham participação fundamental nas finanças familiares antes do aprisionamento (CRUZ, 2018). Ao se abordar tal realidade, o problema objeto da investigação científica proposta é: por que as mulheres se submetem ao tráfico de drogas no estado de Minas Gerais e arriscam sua vida e liberdade? A partir das reflexões preliminares sobre o tema, é possível afirmar inicialmente que as mulheres se submetem ao tráfico de drogas, principalmente, em razão de relações íntimo-afetivas. A conduta criminosa feminina associa-se com a subordinação por gênero, as mulheres ingressam no tráfico a fim de provar lealdade ao companheiro e passam a desempenhar funções secundárias, pelas quais esperam receber algum tipo de reconhecimento pelos homens. Portanto, o objetivo geral do trabalho é analisar 
Personalidade Acadêmica Homenageada:

Augustus B. Cochran III (Agnes Scott College)

as principais causas que justificam a participação de mulheres no tráfico que posteriormente as levam ao encarceramento em Minas Gerais. No tocante ao tipo de investigação, foi escolhido, na classificação de Witker (1985) e Gustin (2010), o tipo jurídico-projetivo. O raciocínio desenvolvido na pesquisa será predominantemente dialético. De acordo com a técnica de análise de conteúdo, afirma-se que se trata de uma pesquisa teórica, o que será possível a partir da análise de conteúdo dos textos doutrinários, normas e demais dados colhidos na pesquisa. Como conclusão parcial do trabalho tem-se que o estado de Minas Gerais demonstra sucumbir ao descaso nacional para com essas mulheres, e se mostra inapto a oferecer auxílios básicos dentro dos presídios, como infraestrutura adequada e empregos, como também no que se refere à criação de políticas públicas que visam mitigar os efeitos desse encarceramento em massa nas famílias das presas, principalmente com relação à seus filhos. Na produção desta pesquisa, foi utilizado como marco teórico as ideias contidas no livro "Prisioneiras", do médico Antônio Drauzio Varella, que propõe como teoria conceitual que, o fato da grande maioria dessas mulheres morarem em uma comunidade, em situação de pobreza, e terem constantemente contato com o mundo do crime as deixa mais propensas a fazer parte dele, o enxergando muitas vezes como a "única saída".

PALAVRAS-CHAVE: Encarceramento feminino; tráfico de drogas; mulheres no tráfico; submissão por gênero.

\section{REFERÊNCIAS}

BRASIL. Ministério da Justiça e Segurança Pública. Departamento Penitenciário Nacional. Levantamento Nacional de Informações Penitenciárias - Infopen Mulheres. $2^{\mathrm{a}}$ edição. Brasília, 2018.

CHERNICHARO, Luciana Peluzio. Sobre mulheres e prisões: seletividade de gênero e crime de tráfico de drogas no Brasil. 2014. Dissertação (Mestrado em Direito) - Universidade Federal do Rio de Janeiro, Rio de Janeiro, 2013. 
Personalidade Acadêmica Homenageada:

Augustus B. Cochran III (Agnes Scott College)

CRUZ, Luana. Amor bandido é chave de cadeia: estudo sobre mulheres encarceradas em Minas Gerais. Portal Minas faz ciência. 16 abr. 2018. Disponível em: http://minasfazciencia.com.br/2018/04/16/amor-bandido-e-chave-de-cadeia-estudosobre-mulheres-encarceradas-em-minas-gerais/. Acesso em: 09 maio 2019.

GUSTIN, Miracy Barbosa de Sousa; DIAS, Maria Tereza Fonseca. (Re)pensando a pesquisa jurídica: teoria e prática. 3ª . ed. Belo Horizonte: Del Rey, 2010.

\#MULHERESEMPRISAO. Desafios e possibilidades para reduzir a prisão provisória de mulheres. São Paulo, 2017. Disponível em: http://ittc.org.br/mulheresemprisao/. Acesso em: 10 mai 2019.

MUSUMECI, Bárbara e ILGENFRITZ, Lara. Prisioneiras: vida e violência atrás das grades. Rio de Janeiro: Garamond, 2002.

PRADO, Alessandra; OLIVEIRA, Débora. A punição de mulheres traficantes: análise crítica de sentenças condenatórias à pena privativa de liberdade não substituída por restritiva de direitos. Revista jurídica UNICURITIBA, Curitiba, v. 1, n. 42, p. 214-230, 2016.

Disponível

em: http://revista.unicuritiba.edu.br/index.php/RevJur/article/view/1491/1020. Acesso em: 20 maio 2019.

UNIVERSIDADE FEDERAL DE MINAS GERAIS. Programa de extensão culthis. Cartilha da pessoa presa e seus familiares. Belo Horizonte: CULTHIS, 2014.

QUEIROZ, Nana. Presos que Menstruam. Rio de Janeiro: Record, 2015.

VARELLA, Drauzio. Prisioneiras. São Paulo: Companhia das Letras, 2017.

WITKER, Jorge. Como elaborar uma tesis en derecho: pautas metodológicas y técnicas para el estudiante o investigador del derecho. Madrid: Civitas, 1985. 